University of Nebraska - Lincoln

DigitalCommons@University of Nebraska - Lincoln

\title{
Identification of 24 polymorphic microsatellite markers for the double-crested cormorant (Phalacrocorax auritus)
}

Jennifer A. Fike

Purdue University

Travis L. DeVault

USDA/APHIS/WS National Wildlife Research Center, Travis.L.DeVault@aphis.usda.gov

Olin E. Rhodes Jr.

Purdue University, rhodes@srel.uga.edu

Follow this and additional works at: https://digitalcommons.unl.edu/icwdm_usdanwrc

Part of the Environmental Sciences Commons

Fike, Jennifer A.; DeVault, Travis L.; and Rhodes, Olin E. Jr., "Identification of 24 polymorphic microsatellite markers for the double-crested cormorant (Phalacrocorax auritus)" (2009). USDA National Wildlife Research Center - Staff Publications. 847.

https://digitalcommons.unl.edu/icwdm_usdanwrc/847

This Article is brought to you for free and open access by the U.S. Department of Agriculture: Animal and Plant Health Inspection Service at DigitalCommons@University of Nebraska - Lincoln. It has been accepted for inclusion in USDA National Wildlife Research Center - Staff Publications by an authorized administrator of DigitalCommons@University of Nebraska - Lincoln. 
libraries enriched for several microsatellite sequences in plants. BioTechniques, 20, 758-760.

Kijas JM, Fowler JC, Garbett CA, Thomas MR (1994) Enrichment of microsatellites from the citrus genome using biotinylated oligonucleotide sequences bound to streptavidin-coated magnetic particles. BioTechniques, 16, 656-660.

Larno V, Launey S, Devaux A, Laroche J (2005) Isolation and characterization of microsatellite loci from chub Leuciscus cephalus (Pisces: Cyprinidae). Molecular Ecology Notes, 5, 752-754.

Mesquita N, Cunha C, Hänfling B et al. (2003) Isolation and characterization of polymorphic microsatellite loci in the endangered Portuguese freshwater Squalius aradensis (Cyprinidae). Molecular Ecology Notes, 3, 572-574.
Muenzel FM, Sanetra M, Salzburger W, Meyer A (2007) Microsatellites from the vairone Leuciscus souffia (Pisces: Cyprinidae) and their application to closely related species. Molecular Ecology Notes, 7, 1048-1050.

Turner TF, Dowling TE, Broughton RE, Gold JR (2004) Variable microsatellite markers amplify across divergent lineages of cyprinid fishes (subfamily Leusicinae). Conservation Genetics, 5, 279-281.

doi: 10.1111/j.1755-0998.2009.02594.x

(C) 2009 Blackwell Publishing Ltd

\title{
Identification of 24 polymorphic microsatellite markers for the double-crested cormorant (Phalacrocorax auritus)
}

\author{
JENNIFER A. FIKE, ${ }^{*}$ TRAVIS L. DEVAULT + and OLIN E. RHODES* \\ *Department of Forestry and Natural Resources, 715 West State Street, Purdue University, West Lafayette, IN 47907, USA. +US \\ Department of Agriculture, Wildlife Services, National Wildlife Research Center, 6100 Columbus Avenue, Sandusky, OH 44870, USA
}

\begin{abstract}
Twenty-four polymorphic microsatellite markers were developed for the double-crested cormorant (Phalacrocorax auritus). The number of alleles ranged from two to 13 and observed heterozygosities ranged from 0.032 to 0.871 . The use of these loci should enable researchers and biologists to learn more about the population structure and ecology of this species.
\end{abstract}

Keywords: colonial-nesting birds, double-crested cormorant, microsatellite, Phalacrocorax auritus

Received 2 December 2008; accepted 25 January 2009

Populations of double-crested cormorants (Phalacrocorax auritus), large, fish-eating, colonial-nesting waterbirds, increased dramatically from the mid-1970s until recently throughout the central and eastern USA (Hatch 1995; Weseloh et al. 1995). The increase in population sizes, coupled with an opportunistic foraging behaviour, has led to conflicts with commercial and recreational fishing (Rudstam et al. 2004) and aquaculture (Taylor \& Dorr 2003). Furthermore, the emergence of large nesting colonies of double-crested cormorants has had adverse impacts on other colonial-nesting birds (Shieldcastle \& Martin 1999) and sensitive vegetation (Hebert et al. 2005). As a result, cormorants are managed aggressively on their breeding and wintering grounds and during migration to alleviate biological damage and reduce conflicts with human interests (Bedard et al. 1999; DeVault et al. 2009). However, to more effectively manage cormorants, further information concerning population sizes, reproductive rates and migration patterns is needed. The availability of microsatellite markers for the double-crested cormorant will help resea-

Correspondence: Jennifer Fike, Fax: (765) 494-9461;

E-mail: jfike@purdue.edu rchers explore these questions and aid in the management of this species.

Two genomic libraries enriched for either tetranucleotide $\left[(\mathrm{GATA})_{7},(\mathrm{GATC})_{7}\right.$, and $\left.(\mathrm{GACA})_{7}\right]$ or dinucleotide $\left[(\mathrm{GT})_{12}\right.$ and $(\mathrm{CT})_{12}$ ] repeats were prepared using a microsatellite cloning protocol based on Hamilton et al. (1999) and Hauswaldt \& Glenn (2003), modified as reported earlier (Beheler et al. 2004). To construct the library, we used a pooled sample of genomic DNA from two double-crested cormorants, which we extracted from muscle tissue using an ammonium acetate protocol (modified from the PUREGENE kit; Gentra Systems). Seven hundred and sixty-eight colonies were screened and sequenced. Sequence data were imported into Sequencher 4.1 (Gene Codes Corporation) for analysis.

We selected a subset $(n=51)$ of microsatellite-containing sequences and designed primers for polymerase chain reaction (PCR) amplification of these microsatellites using the software program Primer 3 (Rozen \& Skaletsky 2000). We amplified these 51 microsatellite loci in 10- $\mu$ L PCRs using a Mastercycler ep gradient (Eppendorf) and $20 \mathrm{ng}$ of template DNA, $0.2 \mathrm{~mm}$ of each dNTP, $0.25 \mu \mathrm{M}$ of each primer, $1 \mathrm{U}$ of Taq DNA polymerase (NEB), $1.25 \mathrm{~mm} \mathrm{MgCl}_{2}$ and $1 \times$ reaction buffer $(10 \mathrm{~mm}$ Tris $-\mathrm{HCl}, 50 \mathrm{~mm} \mathrm{KCl}$, 
1184 PERMANENT GENETIC RESOURCES NOTE

Table 1 Characterization of 24 polymorphic microsatellite loci developed for the double-crested cormorant

\begin{tabular}{|c|c|c|c|c|c|c|c|}
\hline Locus & GenBank no. & Primer sequence & Motif & PCR product (bp) & $A$ & $H_{\mathrm{E}}$ & $H_{\mathrm{O}}$ \\
\hline COR 01 & FJ477898 & $\begin{array}{l}\text { F: TCATGAACCAGCACCACATAG } \\
\text { R: TTGATAGGCAGGTGACATGG }\end{array}$ & $(\mathrm{GATA})_{4,7}$ & 154-198 & 10 & 0.778 & 0.839 \\
\hline COR 03 & FJ477899 & $\begin{array}{l}\text { F: TGCAGTTGCATTCCCTTTC } \\
\text { R: CTTCCTAATGTGTTACACTGTCTGG }\end{array}$ & $(\mathrm{TATC})_{17}$ & $180-234$ & 10 & 0.879 & 0.871 \\
\hline COR 05 & FJ477900 & $\begin{array}{l}\text { F: AGGAACAACAACTGTGATTTGG } \\
\text { R: CTTCAATGCCTTTCTCAAACC }\end{array}$ & $(\mathrm{GATA})_{7}$ & $233-265$ & 9 & 0.797 & $0.677 \dagger$ \\
\hline COR 06 & FJ477901 & $\begin{array}{l}\text { F: GCCCACCATTCTTATTGCAC } \\
\text { R: AGAAAGAATTGAGCCTAAGAAGTGA }\end{array}$ & $(\mathrm{TATC})_{15}$ & $128-184$ & 13 & 0.860 & 0.871 \\
\hline COR 07 & FJ477902 & $\begin{array}{l}\text { F: ACACCATCACAGTGCTTCACC } \\
\text { R: CCCTTTGTCAATCTATGAACAACC }\end{array}$ & $(\mathrm{TGTC})_{5}$ & $131-135$ & 2 & 0.032 & 0.032 \\
\hline COR 12 & FJ477903 & $\begin{array}{l}\text { F: ACGGAGAACACATTTGTTAAGG } \\
\text { R: CTTTCAGACACCCCATTGC }\end{array}$ & $(\mathrm{CT})_{10}(\mathrm{GT})_{5}$ & $217-219$ & 2 & 0.094 & 0.097 \\
\hline COR 15 & FJ477904 & $\begin{array}{l}\text { F: CACCCTTCACAGGTCAGTCA } \\
\text { R: ACGGGGCTTGAACACTTTT }\end{array}$ & $(\mathrm{AC})_{13}$ & $167-177$ & 4 & 0.517 & $0.419+$ \\
\hline COR 17 & FJ477905 & $\begin{array}{l}\text { F: CTGCCTCACTGATGTAAATGC } \\
\text { R: ACACTCCAGTGACTGCCAAA }\end{array}$ & $(\mathrm{AC})_{12}$ & $228-234$ & 3 & 0.539 & 0.516 \\
\hline COR 19 & FJ477906 & $\begin{array}{l}\text { F: CTACAAGTTTCTACTAACGTGTGTGTC } \\
\text { R: GCTGTAAGCTTTTCAGACTGC }\end{array}$ & $(\mathrm{GT})_{20}$ & 118-142 & 6 & 0.707 & 0.645 \\
\hline COR 20 & FJ477907 & $\begin{array}{l}\text { F: CGGTTAACCCACTCAATGC } \\
\text { R: GGGAGAAGTGATGTTGTTTGG }\end{array}$ & $(G T)_{6,10}$ & $168-178$ & 4 & 0.533 & $0.484 \dagger$ \\
\hline COR 21 & FJ477908 & $\begin{array}{l}\text { F: GAACTTGGCAGCTTGCATC } \\
\text { R: ACCAGAGAGTCCTCCGTGTG }\end{array}$ & $(\mathrm{AC})_{20}$ & $151-167$ & 5 & 0.705 & $0.613+$ \\
\hline COR 22 & FJ477909 & $\begin{array}{l}\text { F: CCCCGCTTCCTCTTATATTTG } \\
\text { R: TTGCAGATCCCCAAAATACTG }\end{array}$ & $(\mathrm{GT})_{15}$ & $394-398$ & 3 & 0.476 & 0.581 \\
\hline COR 23 & FJ477910 & $\begin{array}{l}\text { F: CCTGCAATTTCCTGGAGCTA } \\
\text { R: TATTTGGCTGACCCTCTGCT }\end{array}$ & $(\mathrm{GAGT})_{7}$ & $263-275$ & 3 & 0.386 & 0.367 \\
\hline COR 26 & FJ477911 & $\begin{array}{l}\text { F: CACAGCAGTTCAGCATCAGTC } \\
\text { R: CGGGATGAAAAGAAACCTAGAG }\end{array}$ & $(\mathrm{GT})_{11}$ & 177-181 & 2 & 0.178 & $0.129+$ \\
\hline COR 28 & FJ477912 & $\begin{array}{l}\text { F: ATGACAGATGGCGAAAGGTC } \\
\text { R: AAACACATTGGCTCCTCCAG }\end{array}$ & $(\mathrm{AC})_{12}$ & $165-174$ & 4 & 0.714 & 0.742 \\
\hline COR 30 & FJ477913 & $\begin{array}{l}\text { F: ACGAAGTGAGCGTGTGAGTG } \\
\text { R: CAGCTGTTGAACACAAGCAAC }\end{array}$ & $(\mathrm{GT})_{8}$ & $335-357$ & 7 & 0.759 & 0.742 \\
\hline COR 31 & FJ477914 & $\begin{array}{l}\text { F: TTGTTTCATTGACCTGGCTTC } \\
\text { R: GCTGCCACTCTCCATATTCC }\end{array}$ & $(\mathrm{GT})_{9}$ & $222-226$ & 2 & 0.275 & 0.323 \\
\hline COR 35 & FJ477915 & $\begin{array}{l}\text { F: GATTCCACCCAGTCAAATTCC } \\
\text { R: TAGGATCAGCTCCCAACAGC }\end{array}$ & $(\mathrm{GT})_{9}(\mathrm{AG})_{4}$ & $245-247$ & 2 & 0.063 & 0.065 \\
\hline COR 38 & FJ477916 & $\begin{array}{l}\text { F: GTGGAGCACTGGAACAAGC } \\
\text { R: TTTGACAGGACACCAAGATCC }\end{array}$ & $(\mathrm{AC})_{9}$ & $301-307$ & 4 & 0.690 & 0.645 \\
\hline COR 40 & FJ477917 & $\begin{array}{l}\text { F: GAAACCTACCCTTCAAACTAGGC } \\
\text { R: TTCTAGAAATATACAGGGAGGAGAGG }\end{array}$ & $(\mathrm{GT})_{10}$ & 160-166 & 5 & 0.711 & $0.581+$ \\
\hline COR 41 & FJ477918 & $\begin{array}{l}\text { F: TTCCTCTGCTGGATGGAC } \\
\text { R: AACTTACAGCAGACAGGTAATGG }\end{array}$ & $(\mathrm{GT})_{10}$ & 168-182 & 6 & 0.527 & 0.516 \\
\hline COR 43 & FJ477919 & $\begin{array}{l}\text { F: CAGCAGAAGGCAGATACAGC } \\
\text { R: AGACCATGGTATTTGCAGAGG }\end{array}$ & $(\mathrm{AC})_{12}$ & $372-382$ & 5 & 0.633 & $0.548+$ \\
\hline COR 45 & FJ477920 & $\begin{array}{l}\text { F: CAATTCATCCTGCTACACTGC } \\
\text { R: TAGCAGCAGACATGCAAGG }\end{array}$ & $(\mathrm{GT})_{12}$ & $259-263$ & 4 & 0.387 & 0.419 \\
\hline COR 47 & FJ477921 & $\begin{array}{l}\text { F: AAGATTAGTGCAAGTCTTCTCTGC } \\
\text { R: TCGCATCTTGGTGTTATGG }\end{array}$ & $(\mathrm{GT})_{20}$ & 167-181 & 6 & 0.560 & 0.548 \\
\hline
\end{tabular}

The number of alleles $(A)$, expected $\left(H_{\mathrm{E}}\right)$ and observed $\left(H_{\mathrm{O}}\right)$ heterozygosities are reported. Loci were screened in 31 individuals; + frequency of null alleles $>0.05$.

$0.05 \mathrm{mg} / \mu \mathrm{L}$ BSA). The amplification conditions were as follows: $94{ }^{\circ} \mathrm{C}$ for $2 \mathrm{~min}$, then $94^{\circ} \mathrm{C}$ for $30 \mathrm{~s}, 64^{\circ} \mathrm{C}$ for $15 \mathrm{~s}$, $72{ }^{\circ} \mathrm{C}$ for $15 \mathrm{~s}$ for 30 cycles, then $72{ }^{\circ} \mathrm{C}$ for $10 \mathrm{~min}$ and a final extension at $60{ }^{\circ} \mathrm{C}$ for $45 \mathrm{~min}$. PCR products were initially screened on $2 \%$ agarose gels stained with ethidium bromide to verify amplification. Forty-six of the 51 loci consistently produced products of the expected size and subsequently were screened for polymorphism using a panel of 31 double-crested cormorant samples collected near Lake Guntersville, Alabama. The protocols for this polymorphism screening were the same as those given above, except that (i) in each reaction, the concentration of dTTP was reduced to $0.15 \mathrm{~mm}$ and $0.05 \mathrm{~mm}$ of chromatide rhodamine green 5dUTP (Molecular Probes) was added, 
and (ii) PCR products were run on an ABI 3730 automated sequencer (Applied Biosystems) and genotypes were assigned using GeneMapper version 3.7 (Applied Biosystems). Of the 46 primer sets screened, 24 exhibited polymorphism.

For each polymorphic locus, we calculated observed heterozygosity, expected heterozygosity and null allele frequencies using Cervus 1.0 (Marshall et al. 1998). GenePop version 3.4 (Raymond \& Rousset 2000) was used to test for evidence of linkage disequilibrium and deviations from Hardy-Weinberg equilibrium. The number of alleles per locus ranged from two to 13 , and single locus heterozygosities ranged from 0.032 to 0.871 (Table 1 ). None of the 24 loci were found to be out of Hardy-Weinberg equilibrium $(P<0.05)$. Evidence of null alleles was detected at seven loci (Table 1). We tested 276 pairwise comparisons and found no evidence for genotypic linkage disequilibrium between any set of paired loci after a sequential Bonferroni correction was applied $(P<0.00004)$.

\section{Acknowledgements}

We thank Katie Hanson, Elizabeth Cranker, Josh Friers, and Brian Dorr for assistance with obtaining the cormorant samples. We also thank the many biologists and technicians with USDA Wildlife Services throughout the eastern USA who salvaged cormorants for this study. Funding for this research was provided by the US Department of Agriculture, Wildlife Services, New York Program and Purdue University.

\section{References}

Bedard J, Nadeau A, Lepage M (1999) Double-crested cormorant culling in the St. Lawrence River Estuary: results of a 5-year program. In: Symposium on Double-Crested Cormorants: Population Status and Management Issues in the Midwest (ed. Tobin ME, Tech. Coord). USDA, Animal and Plant Health Inspection Service, Technical Bulletin No 1879.

Beheler AS, Fike JA, Murfitt LM, Rhodes OE Jr, Serfass TS (2004) Development of polymorphic microsatellite loci for North American river otters (Lontra canadensis) and amplification in related Mustelids. Molecular Ecology Notes, 4, 56-58.
DeVault TL, Chipman RB, Barras SC et al. (2009) Reducing impacts of double-crested cormorants to natural resources in central New York: review of a collaborative research, management, and monitoring program. Waterbirds (in press).

Hamilton MB, Pincus EL, Di Fiore A, Fleischer RC (1999) Universal linker and ligation procedures for construction of genomic DNA libraries enriched for microsatellites. BioTechniques, 27, 500-507.

Hatch JJ (1995) Changing populations of double-crested cormorants. Colonial Waterbirds, 18, 8-24.

Hauswaldt SJ, Glenn TC (2003) Microsatellite DNA loci from the diamondback terrapin (Malaclemys terrapin). Molecular Ecology Notes, 3, 174-176.

Hebert CE, Duffe J, Weseloh DVC, Senese EMT, Haffner GD (2005) Unique island habitats may be threatened by double-crested cormorants. Journal of Wildlife Management, 69, 68-76.

Marshall TC, Slate J, Kruuk LEB, Pemberton JM (1998) Statistical confidence for likelihood-based paternity inference in natural populations. Molecular Ecology, 7, 639-655.

Raymond M, Rousset F (2000) GenePop version 3.4. Available at URL: http://wbiomed.curtin.edu.au/genepop

Rozen S, Skaletsky HJ (2000) Primer 3. Available at URL: http:// frodo.wi.mit.edu/cgi-bin/primer3/primer3_www.cgi

Rudstam LG, VanDeValk AJ, Adams CM et al. (2004) Cormorant predation and the population dynamics of walleye and yellow perch in Oneida Lake. Ecological Applications, 14, 149-163.

Shieldcastle MC, Martin L (1999) Colonial waterbird nesting on West Sister Island National Wildlife Refuge and the arrival of double-crested cormorants. In: Symposium on Double-Crested Cormorants: Population Status and Management Issues in the Midwest (ed. Tobin ME Tech. Coord). USDA, Animal and Plant Health Inspection Service, Technical Bulletin No 1879.

Taylor JD, Dorr BS (2003) Double-crested cormorant impacts to commercial and natural resources. Proceedings of the 10th Wildlife Damage Management Conference, 43-51.

Weseloh DVC, Ewins PJ, Struger J et al. (1995) Double-crested cormorants of the Great Lakes: changes in population size, breeding distribution, and reproductive output between 1913 and 1991. Colonial Waterbirds, 18 (Special Publication 1), 48-59.

doi: 10.1111/j.1755-0998.2009.02596.x

(C) 2009 Blackwell Publishing Ltd

\title{
Isolation and characterization of nine microsatellite loci in an ant-tended treehopper Publilia concava
}

\author{
VIKRAM CHHATRE, * MANUEL A. MORALES + and PATRICK ABBOT* \\ *Department of Biological Sciences, Vanderbilt University, Nashville, TN 37235, USA, +Department of Biology, Williams College, \\ Williamstown, MA 01267, USA
}

\begin{abstract}
Publilia concava is an eastern North American membracid commonly occurring in large but spatially patchy aggregations, primarily on the host plant Solidago altissima. Like other
\end{abstract}

Correspondence: Patrick Abbot, Fax: (615) 343-6707; E-mail: partick.abbot@vanderbilt.edu 